\title{
Epidemiological profile of Ascariasis in Provincial General Reference Hospital of Kinshasa, Democratic Republic of the Congo
}

\author{
Motuta Amisi Christian ${ }^{1,2}$, Djolu Djoza Ruphin ${ }^{3}$, Masengo Ashande Colette ${ }^{3}$, Gbolo \\ Zoawe Benjamin ${ }^{3}$, Bongo Ngiala Gédéon ${ }^{3}$, Lengbiye Moke Emmanuel ${ }^{4}$, Mbembo-Wa- \\ Mbembo Blaise ${ }^{4}$, Koto-te-Nyiwa Ngbolua ${ }^{1,3,4,5}$ \\ ${ }^{1}$ Faculty of Medicine, University of Gbado-Lite, Gbado-Lite City, Democratic Republic of the Congo \\ 2Department of Clinical Biology, Provincial General Reference Hospital of Kinshasa, Kinshasa City, \\ Democratic Republic of the Congo \\ ${ }^{3}$ Faculty of Science, University of Gbado-Lite, Gbado-Lite City, Democratic Republic of the Congo \\ ${ }^{4}$ Faculty of Science, University of Kinshasa, Kinshasa City, Democratic Republic of the Congo \\ ${ }^{5}$ Environment Management and Geography Department, Higher Pedagogical Institute of \\ Abumombazi, Abumombazi, Democratic Republic of the Congo \\ E-mail: jpngbolua@unikin.ac.cd
}

\begin{abstract}
:
A cross sectional study was carried out on intestinal ascariasis, which is a helminth of fecal peril that colonizes the digestive tract with the possibility of complications in organs such as the intestines, liver, lungs and even the brain. The study was carried out at the General Reference Hospital of Kinshasa where medical records were used to collect data and the study period was from January 2016 and December 2017. The findings show females (61.19\%) are predominant than males $(38.80 \%)$, and the gender sex ratio (M/F) was 0.63 . The incidence was high in June 2016 and November 2017 are the most affected months by Ascariasis in our study with 7 cases or $18.98 \%$ and 6 cases or $20 \%$ for each year. The age group between 31 - 40 years of age predominated by the attack of this parasitic affection with the extreme ages of 8 months and 75 years. The incidence varied with a peak in June with 7 cases or $18.98 \%$. A variable incidence with a peak in November with 6 cases or $20 \%$.
\end{abstract}

Keywords:

intestinal ascariasis; helminth; parasitic disease; Kinshasa

\section{Introduction}

Ascaris lombricoides is a nematode worm (genus ascaris), an intestinal parasite that causes ascariasis, a strictly human disease. It is the largest of the nematodes, and the most common helminthiasis, which affects humans (Pilly, 2016; Aubry \& Bandjie, 2013; Desoubeaux \& Chandenier, 2012; El Guamri et al., 2008; Brumpt, 1949). Roundworms are cosmopolitan but are more common in tropical and subtropical areas and in areas with inadequate hygiene (Gentillini \& Duflo, 1993). Widespread throughout the world, digestive parasites caused by nematodes are among the most common infections and affect the poorest and most disadvantaged communities (Golvan, 1983 ; Manet et al. 1971). Ascariasis is the geohelminthiasis of all its diseases, reaching almost the entire world population, with a strong predominance in developing countries where different factors contribute to its transmission (Aubry \& Bernard-Alex, 2018; Laamraniel et al., 1999). This disease represents a real public health problem among the 1450 million people infected with roundworm, 350 million of which are seriously affected by this cosmopolitan verminosis causing 60,000 deaths annually, according to the WHO (Bourrée, 2013). While a recent estimate of 1221 billion roundworm infestations has been also reported (Bourré, 2001). The prevalence of ascariasis varies greatly from region to region: while it tends to disappear from temperate regions, where it was usually 
mild, it continues to be used at high rates in hot countries and has a significant impact on the infant mortality rate (Bourré, 2008). In Africa, it occupies a major place, favored by its important tropical geographical situation but also by its economic situation or promiscuity: the lack of hygiene and sanitation contribute to its presence, its spread and even its resurgence

(Guillaume, 2007). In the Democratic Republic of Congo (DRC), almost the entire population is affected at some point in their lives and the high prevalence of this parasitosis is one of the many factors contributing to its resistance. The omnipresence of the disease is compounded by the socio-economic instability that disrupts the health system, the cost of medicines and the difficulty of distributing them and monitoring treatment (Nicolas et al., 2001). The incidence of this disease is particularly high in countries such as ours, where parasitosis is much more common in densely populated communities with low living standards. Kinshasa city, which is densely populated, represents a favorable environment for Ascariasis, with all the favorable conditions it abounds in. But also due to a considerable lack of knowledge by some practitioners of the disease which, often leads to misdiagnosis and mismanagement, even if the disease is not lethal, it weakens the organism by increasing the under nutrition, which will make the organism unable to defend itself against other pathologies. Therefore, it has important socio-economic consequences, justifying appropriate diagnostic and therapeutic care. The aim of the present study is to evaluate the epidemiological profile of Ascariasis in Provincial General Reference Hospital of Kinshasa, Democratic Republic of the Congo.

\section{Research Methods}

A retrospective cross-sectional study on the epidemiological profile of Ascariasis from January 2016 to December 2017 was carried out in the Department of Parasitology, Provincial General Reference Hospital of Kinshasa; a health facility located in Gombe municipality, in Kinshasa city, the capital of DRC. The data were collected through survey questionnaire containing socio-demographic variables (age and sex) and para-clinical/lab results. The study concerns two categories of patients, namely: outpatients and those who are admitted in this health facility precisely in Pediatrics, Internal Medicine, Surgery and Obstetric Gynecology departments who have been referred to the Parasitology Department. A total of 2,122 patients referred to the parasitology department (1,259 in 2016 and 863 in 2017) were registered according to the prescription of the attending physician, among which 67 patients suffering from ascariasis were selected. As criteria selection, a fresh stool sample is analyzed within one hour after the coprological specimen is given for were or each patient; the most specific diagnostic method is the detection of parasites in direct and concentrated stools (presence of oval and symmetrical roundworm eggs); having been recorded in the results register containing the parameters of interest for the study. Data were entered into Microsoft Excel and analyzed using SPPS 20 software package. The principles of confidentiality were respected during the collection and processing of data. Since the statistics are part of the day-to-day activities of the Clinical Biology Department, informed consent was not required as the work has been done on registries. Each patient collection form was coded; under no circumstances were data related to the names of individuals not published. 


\section{Discussion}

The socio-demographics characteristics of respondents are presented in table 1.

Table 1. Socio-demographics characteristics of patients

\begin{tabular}{llcc}
\hline Variables & & Frequency & Percentage \\
\hline Sex & Male & 26 & 38,80 \\
& Female & 41 & 61,19 \\
\hline Age (years) & $<10$ & 7 & 10,44 \\
& $11-20$ & 10 & 14,92 \\
& $21-30$ & 12 & 17,91 \\
& $31-40$ & 15 & 22,38 \\
& $41-50$ & 11 & 16,44 \\
& $51-60$ & 6 & 8,95 \\
& $>60$ & 6 & 8,95 \\
\hline
\end{tabular}

As observed in the table 1 , there is a predominance of female $(61.19 \%)$ than male $(38.80 \%)$, while the sex ratio $(\mathrm{M} / \mathrm{F})$ is 0.63 . Out of the 67 patient records, the most affected age group is between 31 and 40 years, follow by the range of 21-30 years, which represent $22.38 \%$ and $17.91 \%$ respectively. The table 2 gives the distribution of patients according to the months.

Table 2. Monthly distribution of cases during the study period

\begin{tabular}{lcccc}
\hline \multirow{2}{*}{ Month } & \multicolumn{2}{c}{2016} & \multicolumn{2}{c}{$\mathbf{2 0 1 7}$} \\
\cline { 2 - 5 } & No patients & $\mathbf{\%}$ & No patients & $\mathbf{\%}$ \\
\hline January & 4 & 10.1 & 1 & 3.3 \\
February & 2 & 5.4 & 3 & 10 \\
March & 2 & 5.4 & 4 & 13.3 \\
April & 2 & 5.4 & 0 & 0 \\
May & 4 & 10.1 & 2 & 6.6 \\
June & 7 & 18.9 & 3 & 10 \\
July & 0 & 0 & 2 & 6.6 \\
August & 2 & 5.4 & 0 & 0 \\
September & 1 & 2.7 & 1 & 3.3 \\
October & 4 & 10.1 & 3 & 10 \\
November & 5 & 13.5 & 6 & 20 \\
December & 4 & 10.9 & 5 & 16.6 \\
\hline Total & $\mathbf{3 7}$ & $\mathbf{1 0 0}$ & $\mathbf{3 0}$ & $\mathbf{1 0 0}$ \\
\hline
\end{tabular}

From the table, it is observed an incidence varying between months having a peak in June for 2016 (18.9\%) and in November for 2017 (20\%).

Considering the lab results, it was observed that during microscopic examination carried out in the laboratory, several other intestinal parasites were identified in the stools emitted by patients, among which, Blastocystis hominis, Entamoeba coli, Giardia intestinalis, Endolimax nana, Entamoeba histolytica, Pseudolimax butschlii, Enterobius vermicularis, Cryptosporidium sp and Taenia saginata. Intestinal parasitosis now seems to be attracting less and less attention because of the justified diversion of available resources to newer priorities such as AIDS. These conditions should not be neglected and should not be relegated to the back burner, given the public health problems they pose to our developing countries. Research must always 
be carried out to better understand the problem in all countries in order to eradicate this disease forever. In this study, a frequency of parasitic infestation due to roundworms was found to be $3.15 \%$ in all patients referred to the parasitology department during the study period. This frequency reflects many more cases of carriers of roundworm eggs or ascariasis infection. All ages were affected by ascariasis. The youngest patient in our series was 8 months old; the oldest was 75 years old. The age group most affected by ascariasis was 31 to 40 years old, while those from 51 to 60 years old and over 60 years old were only slightly affected. The most common form of ascariasis for all age groups was roundworm eggs. In this study, the predominance of the female sex was observed with $61.19 \%$ against $38.80 \%$ for the male sex was diagnosed with ascariasis due to the presence of one or more roundworm eggs in the stool. These findings corroborate with those of Bourré et al. (2013) and Pilly (2016), who observed a higher number of female subjects than male parasitized subjects. It is believed that this increase in frequency is due to the household activities of women who are more in contact with the garbage that exposes them to the infestation (Pilly, 2016). The study period was of a 24-month (between January 2016 and December 2017), and it was established that there was a predominance of ascariasis cases during June 2016 (10.44\%) and November 2017 (20\%) with a prevalence of approximately $8.95 \%$ due to poor socio-economic and hygienic conditions. It should be noted that this study is among the first to be conducted in the parasitology department of this health facility on ascariasis.

Ascaris lombricoides is a nematode transmitted by the ingestion of eggs. After the eggs hatch, the larvae penetrate through the intestine and migrate through portal vessels to the liver and lungs where they are coughed out and swallowed. In the intestine, the larvae mature into adult male $(20 \mathrm{~cm}$ long) and female $(30 \mathrm{~cm}$ long) worms. This migratory phase is characterized by inflammatory and hypersensitivity reactions affecting the lungs.

Pathological manifestations induced by adult worms include malabsorption, intestinal obstruction, and invasion of the bile duct or appendix, leading to acute pancreatitis or appendicitis and impaired cognitive function (Scott, 2008). The period from egg ingestion to detection in the feces is 10-11 weeks and the lifespan of adult worms is 1-2 years. During this period, the adults mate and Ascaris eggs are released in the feces. Fecundity thus varies considerably in different geographical areas, ranging from 10 to 220 eggs per female worm and gram of faeces (Hall \& Holland, 2000). These eggs are more resistant to desiccation and can survive up to 15 years under favorable environmental conditions (O'Lorcain \& Holland, 2000). They are also highly adhesive and attach easily to fruits, vegetables, soil, flies and cockroaches. Transmission of Ascaris eggs is ensured by accidental ingestion of soil, geophagy and consumption of contaminated vegetables, leaves and fruits (Gentillini \& Duflo, 1993). In the human host, Ascaris induces a Th2 immune response characterized by elevated IL-4 and IL-5, eosinophilia and Ascaris-specific IgE (Malla et al., N., 2006 ; Bradley \& Jackson, 2004). To this end, it has been shown that continuous exposure to Ascaris eggs from the environment acts as a permanent stimulus maintaining high protective immune responses, and that subjects with a reduced response tend to release more eggs, indicating a weakness in their ability to control the infestation. However, malnutrition impairs immune responses, resulting in increased susceptibility to infection (Scott, 2008). By comparing Kinshasa to the Province of Nord-Ubangi in general and Gbado-Lite city in particular, it can be noted that Ascariasis is also a public health problem in the Ubangi eco-region which is a subgroup of Northeastern Congolian lowland forests. This eco-region is one of the 200 globally priority terrestrial ecoregions known as the "G200" (Ngbolua et al., 2020a, b, Ngbolua et al., 2019a, b, c; Gbolo et al., 2019) and can pay attention in term of future public health research. 


\section{Conclusion}

At last, the frequency of Ascariasis infestation due to roundworm eggs at the Provincial General Reference Hospital of Kinshasa is 100\%; while patients of all ages and both sexes are affected by this condition. The monthly variability was recorded during our study period with peaks in June 2016 and November 2017. Females were most affected as well as the $31-40$ age group.

\section{References}

Aubry, P., Bandjie, M.C.J. (2013). Diagnostic biologique des maladies infectieuses en zones tropicales. http://medecinetropicale.free.fr/cours/diagbiol.pdf.

Aubry, P., Bernard-Alex, G. (2018). Médicine tropicale, parasitoses digestives dues aux nématodes. Centre René La busquière, Institut de Médecine tropicale, université de Bordeaux, 33076 France.

Bourré, P. (2001). Aide-mémoire de parasitologie et de pathologie tropicale, 3ème Edition. Flammarion, Paris: France.

Bourré, P. (2008). Aide-mémoire de parasitologie et de pathologie tropicale, 4ème édition. Flammarion: Paris: France.

Bourré, P. (2013). Ascaridiose. La Revue du Patricien: Médecine générale, 27(903), 468-469.

Bradley, J.E., Jackson, J.A. (2004). Immunity, immunoregulation and the ecology of trichuriasis and ascariasis. Parasite Immunol. 26, 429-441.

Brumpt, E. (1949). Précis de parasitologie, Masson et cie.

Desoubeaux, G., Chandenier, J. (2012). Nématodes intestinales: aspects épidémio-cliniques et diagnostic. Revue Francophone des Laboratoires, 440, 39-55. doi: 10.1016/S1773035X(12)71364-3.

El Guamri, Y., Belghyti, D., Barkia, A., Tiabi, M., Aujjar A.N.A., El kharrim, K., Elfellaki, L. (2008). Enquête épidémiologique rétrospective sur les parasitoses intestinales au Centre hospitalier provincial El Idrissi (Kénitra, Maroc) : bilan de 10 ans (1996-2005) (Maroc). Annales de Biologie Clinique, 67(2), 191-202. doi : 10.1684/abc.2009.0313.

Gbolo, Z.B., Ngbolua, K.N., Mpiana, P.T., Ndanga, B.A., Pangodi, A.J.M., Masengo, A.C., Mudogo, V. (2019). Evaluation of the Clinical Efficiency of an Antisickling Polyherbal Formula Drepanoalpha in a Sickle cell disease Patient in Gbado-Lite City (Democratic Republic of the Congo) by Quantum Magnetic Resonance Analyzer. Britain International of Exact Sciences (BIoEx) Journal, 1(1), 36-48.

Gentillini, M., Duflo, B. (1993). Médecine tropicale, Flammarion Médecine-Sciences: Paris, France.

Golvan, J. (1983). Eléments de parasitologie médicale : Flammarion Médecine-Sciences : Paris, France.

Guillaume, V. (2007). Parasitologie : Fiches pratiques (Autoévaluation et Manipulations), Editions De Boek et Laciers.

Hall, A., Holland, C. (2000). Geographical variation in Ascaris lumbricoides fecundity and its implications for helminth control. Parasitol., 16, 540-544.

Laamraniel, I.A., Lyagoubi, M., Barkia, A., Ayoujil, M. (1999). Prévalence des parasitoses intestinales au niveau de trois provinces au Maroc. La Revue de Santé de la Méditérranée Orientale, 5(1), 86-102.

Malla, N., Fomda, B.A., Thokar, M.A. (2006). Serum cytokine levels in human ascariasis and toxocariasis. Parasitol., 98, 345-348.

Manet, L.L., Savel, J., Giacomini, T., Lamy, C., Petithory, J., Solle, R. (1971). Techniques usuelles de biologique clinique Parasitologie. Flammarion Médecines-Sciences : Paris, France. 
Ngbolua, K.N., Kumbali, N.G., Mbembo-wa-Mbembo, B., Kohowe, P.S., Kogana, K.F., Bongo, N.G., Masengo, A.C., Djolu, D.R. (2020a). First Report on Three Cases of Monkey pox in Nord Ubangi Province (Democratic Republic of the Congo). Britain International of Exact Sciences (BIoEx) Journal, 2(1), 120-125.

Ngbolua, K.N., Ngemale, G.M., Masengo, A.C., Ndolete, G.J.P., Bongo, N.G., Ndanga, B.A., Tshibangu, D.S.T., Tshilanda, D.D. (2020b). Survey on the Sale of Megaphrynium Macrostachyum (Marantaceae) Leaves in Gbado-Lite City and Surroundings (Nord Ubangi Province, Democratic Republic of the Congo). Budapest International Research in Exact Sciences (BirEx) Journal, 2(2), 157-167.

Ngbolua, K.N., Kumbali N.G., Mbembo-wa-Mbembo, B., Djolu D.R., Bongo, N.G., Falanga, M.C., Gbolo, Z.B., Masengo, A.C., Libwa, M.T.B. (2019a). Epidemio-therapeutic Survey on Malnourished Children Aged 0-5 Years Old in the Gbado-Lite Health Zone (Nord Ubangi Province, Democratic Republic of the Congo). Britain International of Exact Sciences (BIoEx) Journal, 1(1), 22-28.

Ngbolua, K.N., Zuangbo, I., Molongo M., Masengo, A.C., Djolu, D.R., Yabuda, H., Bongo, N.G., Gbolo, Z.B., Monde-te-Kazangba, G. (2019b). Effect of Agricultural Residues Based-Compost on the Yield of Amaranthus hybridus L. (Amaranthaceae) in GbadoLite City, Nord-Ubangi (Democratic Republic of the Congo). Budapest International Research in Exact Sciences (BirEx) Journal, 1(4), 53-61.

Ngunde-te-Ngunde, S., Lengbiye, M.E., Tshidibi, D.J., Kengo, V.F., Djolu, D.J., Masengo, A.C., Gbolo, Z.B., Iteku, B.J., Mpiana, P.T., Ngbolua, K.N. (2019c). Antisickling and Antibacterial Activites of Anthocleista schweinfurthii Gilg. (Gentianaceae) from Nonhuman Primates Pharmacopoeia in Democratic Republic of the Congo. Budapest International Research in Exact Sciences, 1(3), 14-20, 2019.

Nicolas, X., Chevalier, B., Simon, F., Klotz, F. (2001). Traitement des parasitoses intestinales (amibiase et mycose excluses), Encycl. Méd. Chir. (Elsevier, Paris), 9-062-A-60.

O'Lorcain, P., Holland, C.V. (2000). The public health importance of Ascaris lumbricoides. Parasitology, 121, S51-S71.

Pilly, E. (2016). Maladies Infectieuses et Tropicales, 25e édition, Alinéa Plus.

Scott, E.M. (2008). Ascaris lumbricoides: analyse de son épidémiologie et de ses relations à d'autres infestations. Ann Nestlé, 66, 7-22. doi: 10.1159/000151322. 